\title{
Investigation of Using Nano-silica, Silica Fume and Fly Ash in High Strength Concrete
}

\author{
Mohamed M. Abu El-Hassan ${ }^{1}$, Gamal M. Kamh ${ }^{2}$, Mohamed A. Fahmy ${ }^{3}$, Alaa A. Bashandy ${ }^{4}$ \\ ${ }^{1}$ Geology Department, Faculty of Science, Menoufia University, Egypt \\ ${ }^{2}$ Geology Department Faculty of Science, Menoufia University, Egypt \\ ${ }^{3}$ Geologist, M. Sc. Candidate \\ ${ }^{4}$ Civil Engineering Department, Faculty of Engineering, Menoufia University, Egypt
}

\begin{abstract}
This study aims to investigate the performance of hardened high strength concrete cast using Nano-silica, silica fume and fly ash. Experiments were conducted by substituting cement by weight with Nano-silica, silica fume or fly ash with ratios of $5 \%, 10 \%$ and $15 \%$ and compared to a control mix. This study generally proposes a sustainable solution to produce durable concrete that could have useful application in the construction industry. Based on the results obtained, the hardened properties of concrete improved depending on the type of supplementary cementious materials. Test results showed that adding the suggested types is effective to improve concrete strength. Adding Nano-silica has a great influence on concrete properties. Increasing the dosage over $5.0 \%$ affects badly on strength.
\end{abstract}

Keywords: High strength concrete; Nano-silica; silica fume; fly ash.

\section{INTRODUCTION}

In the present day, concrete is the most widely-used construction material in the world [1]. The construction industry uses concrete to a large extent. Roughly 35 billion tons used [2]. Due to the great development in the construction industry concrete has developed to keep pace with evolving and requirements of industry, one of the developed concrete is the high strength concrete "HSC". It is used for concrete mixture which has high strength, high workability, high durable, high density, low permeability and resistance to chemical attack as compared to normal strength concrete [3, 4]. High strength concrete "HSC" is often considered a relatively new material; it is improved over years due to the development of concrete additives such as water reducers (plasticizers and super-plasticizers). Definition of the minimum strength value for high-strength concrete varies with time and geographical location depending on the availability of raw material and the technical Know-how, and the demand from the industry [5]. Mechanical properties of HSC are sensitive to the type of coarse aggregates and curing techniques [6]. The primary difference between high-strength concrete and normalstrength concrete relates to the compressive strength that refers to the maximum resistance of a concrete sample to applied loads. HSC can be obtained for some different special concrete types such as self-compacted concrete, self-curing concrete and recycled aggregate concrete [7, $8,9]$.

By using fly ash, silica fume or other pozzolanic materials which are the most commonly used as mineral admixtures in high-strength concrete and ultra-high strength concrete. These materials impart additional strength to the concrete by reacting with Portland cement hydration products to create an additional C-S-H gel, the part of the paste responsible for concrete strength [10]. Addition of silica Nano particles has important implications for the hydration kinetics and the microstructure of the paste such as (a) an increase in the initial hydration rate, (b) an increase of the amount of CS-H gel of the paste through pozzolanic reaction, (c) reduction of porosity, (d) improvement in the mechanical properties of the C-S-H gel itself (e.g., greater aluminacontent, longer silicate chains) [11]. Nano-Silica, as well as silica fume, is a highly reactive pozzolan and could consume calcium hydroxide $(\mathrm{CH})$ to form secondary $\mathrm{C}$ $\mathrm{S}-\mathrm{H}$ [12]. Chemically, Nano-silica addition increases the pozzolanic reactivity when compared to the silica fume $[13,14]$.

Silica is the common name for materials composed of silicon dioxide $\left(\mathrm{SiO}_{2}\right)$ and occurs in crystalline and amorphous forms. SF is also known as micro silica, condensed silica fume, volatilized silica or silica dust [15]. The American concrete institute defines silica fume as "Very fine non-crystalline silica produced in electric arc furnaces as a by-product of the production of elemental silicon or alloys containing silicon". It is a grey coloured powder, similar to Portland cement or fly ash. SF is a very fine powder consisting mainly of spherical particles or microspheres, with a mean diameter of about 0.15 microns, with Avery high specific surface area $\left(15,000-25,000 \mathrm{~m}^{2} / \mathrm{kg}\right)$. Each microsphere is on average 100 times smaller than an average cement grain [16].

Fly ash, another popular pozzolan, can improve concrete properties such as workability, durability, and ultimate strength in hardened concrete [17]. Fly ash (FA) is a fine-grained solid material having a particle size range of $0.2-200 \mathrm{~lm}$. The range of particle size of any given FA 
depends largely on the fineness of the pulverized coal and the type of flue Superior resistance to chemical attack from chlorides, acids, nitrates and sulfates and life-cycle cost efficiencies [18]. It is a fine powder resulting from the combustion of powdered coal transported by the flue gases of the boiler and collected in the Electrostatic Precipitators [19]. Fly ash is a fine powder resulting from the combustion of powdered coal - transported by the flue gas scrubbing systems [20]. Millions of tons of fly ash produced each year due to the massive consumption of coal [21]. Physical properties of fly ash may vary depending on the nature of coal; rank, mineral matter chemistry and mineralogy, furnace design, furnace operation and method of particulate control, while chemical properties are less dependent on those factors [22]. Fly Ash (FA) as a supplementary cementitious material (SCM) increases the sustainability of concrete by decreasing $\mathrm{CO}_{2}$ emissions from cement production. The addition of fly ash leads to higher porosity at a short curing time [23]. When fly ash is mixed with Portland cement and water, it generates a product similar to that formed by cement hydration, but having a denser microstructure that is less permeable [24]. The strength development of FA concrete, particularly that containing Class $\mathrm{F}$ fly ash, is slow compared to normal concrete that is not suitable for many applications where early strength is required, such as repairs and rapid construction [25]. Whereas, concretes containing SF are thought to be more susceptible to plastic shrinkage than any other type of concrete, particularly in structures with large surface areas [26].

In this research, the influence of using NS, SF or FA with high strength concrete with the compressive, tensile, flexure and bond strengths of concrete after different ages, 7, 28 and 56 days, will be studied and evaluated.

\section{RESEARCH SIGNIFICANCE}

Using pozzolanic additives improves concrete characteristics. Changing the pozzolanic additive type changing its effects on concrete. This research aims to study the effects of using different types of pozzolanic additives to obtain structural high strength concrete. The main variables at this investigation are; additive type (fly ash, silica fume, and Nano-silica) and an additive ratio $(5 \%, 10 \%$, and $15 \%)$ of the cement weight. The outputs of this research are experimental results that the researchers can use it to judge and use this type of concrete.

The innovation in this research is the comparative study of the properties and the behaviour of the pozzolanic additives used and their ratios in high strength concrete mixes.

The importance of this research is to provide sufficient data for the researchers and engineers that concerns in using high strength concrete "HSC" and the effects of using different pozzolanic additives to improve it.

\section{EXPERIMENTAL PROGRAM}

\section{Materials}

In the present work, Ordinary Portland Cement (OPC) of "CEM I $42.5 \mathrm{~N}$ " was used. The properties of the cement used were illustrated in Table 1. Basalt rock stones crushed using cone crusher having maximum size 12.5 $\mathrm{mm}$ was used as coarse aggregate. Natural siliceous sand from Naga Hammadi quarries, Qena governorate, was used as fine aggregates. The particle size distributions of fine aggregate and coarse aggregate are shown in Fig. 1 and the properties of aggregates were illustrated in Table 2. The properties of aggregates obtained in the laboratories of the Arab Contractors Company and it is characteristics satisfy the E.S.S. 1109/2008 and the Egyptian Code for Concrete Design E.C.P. 203/2018.

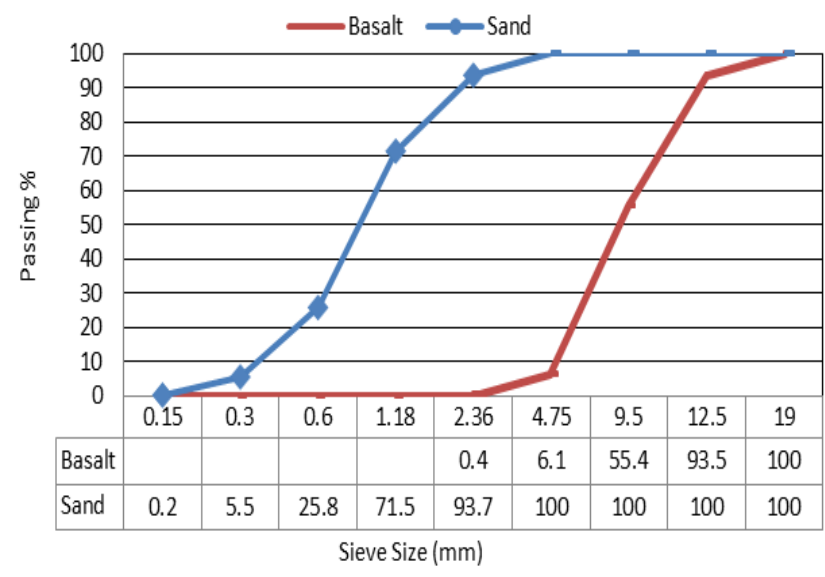

Figure 1- The particle size distribution of fine and coarse aggregate

Tap water was used in this investigation for the mix and cure of concrete mixes. High range water reducer as a super plasticizer was used to improve concrete workability. It obtained from the SIKA Company under a commercial name of Sika ViscoCrete ${ }^{\circledR}-3425$.

Fly ash and silica fume as pozzolanic admixtures were obtained from SIKA Company. Nano-Silica of a crystalline silica particles (in Nano-size) synthesis of topdown techniques in which the large particles convert to small one. Silica used was obtained from Quartz mineral with silica more than $98.9 \%$ come from red sea quartz mining. The Ball milling technique was used to prepare Crystalline Silica Nano particles with multi-steps procedures. Particle size of Nano-silica lies between (40 to $140 \mathrm{~nm}$ ), but the most particle sizes of Nano-silica distribution is about $80 \mathrm{~nm}$ as shown in Fig. 2 .

To obtain Nano-silica properties, XRD tests, TEM image and SEM image were performed. XRD for mineral identification showed that $99.0 \%$ of the sample is composed of $\mathrm{SiO} 2$ as shown in Fig. 3. XRD pattern illustrated synthesis of Nano-quartz without any impurities during the synthesis process as shown in Fig. 4. XRD data illustrated a high crystallinity of Nano- 
quartz with hexagonal lattice structure. Crystal size measuring using XRD data was $22.7 \mathrm{~nm}$. Raman shift curve illustrated the finger print Raman shift curve for quartz mineral without any additional peaks for other was associated minerals, which indicate to the high purity of Nano-quartz. However, there are three very characteristic peaks at $127.57,205.32$ and $464.16 \mathrm{~cm}^{-1}$ and 10 weak peaks at 263,354, 383.18, 384.92, 694.58, 795, 806, 1022, 1085 and $1160 \mathrm{~cm}^{-1}$ as shown in Fig. 4. TEM image (Fig. 5), shows the spherical shape of quartz Nano particles. The agglomeration and concentration were well sorted. SEM image (Fig. 6) showed the 3D spherical shape of quartz Nano particles.

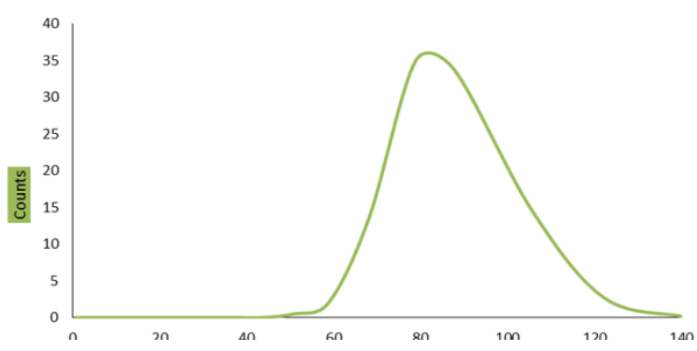

Figure 2- Particle size distribution of silica Nano particles

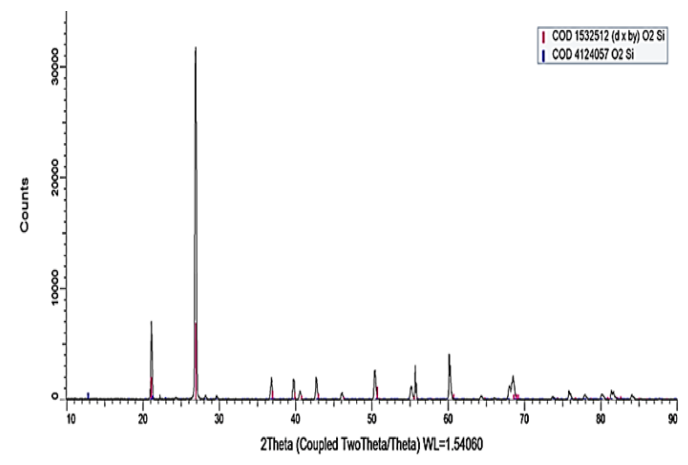

Figure 3- Mineral identification of silica Nanoparticle

Table 1- The properties of the cement used

\begin{tabular}{|c|c|c|}
\hline Test description & Test results & E.S.S. limits \\
\hline Specific gravity & 3.15 & -- \\
\hline $\begin{array}{c}\text { standard consistency } \\
\text { w/c } \%\end{array}$ & $27 \%$ & -- \\
\hline Setting time (Vicat) & $\mathrm{hr}: \min$ & E.S 2421-1/2005 \\
\hline Initial & $2: 30$ & Not less than $60 \mathrm{~min}$. \\
\hline Final & $8: 50$ & Not more than $10 \mathrm{hr}$. \\
\hline Fineness of cement & $7 \%$ & Not more than $10 \%$ \\
\hline $\begin{array}{c}\text { Com. strength } \\
2 \text { days } \\
28 \text { days }\end{array}$ & $\begin{array}{l}18.4 \mathrm{~N} / \mathrm{mm}^{2} \\
44.7 \mathrm{~N} / \mathrm{mm}^{2}\end{array}$ & $\begin{array}{c}\text { E.S } 2421-7 / 2006 \\
10 \mathrm{~N} / \mathrm{mm}^{2} \\
(42.5-62.5) \mathrm{N} / \mathrm{mm}^{2}\end{array}$ \\
\hline Size stability $(\mathrm{mm})$ & $1.0 \mathrm{~mm}$ & $\begin{array}{l}\text { E.S } 2421-1 / 2005 \\
(\text { Not more } 10 \mathrm{~mm})\end{array}$ \\
\hline Loss of burning & $3.02 \%$ & $\begin{array}{l}\text { E.S 5325/2006 } \\
(\text { Not more 5\%) }\end{array}$ \\
\hline Insoluble substances & 1.670 & $\begin{array}{l}\text { E.S 5325/2006 } \\
\text { (Not more 5\%) }\end{array}$ \\
\hline
\end{tabular}

Table 1-continued The properties of the cement used

\begin{tabular}{|c|c|c|}
\hline $\begin{array}{c}\text { Sulfate content } \\
\text { (SO3) }\end{array}$ & 2.470 & $\begin{array}{c}\text { E.S 5325/2006 } \\
\text { (Not more 3.5\%) }\end{array}$ \\
\hline Chloride content & 0.034 & $\begin{array}{c}\text { E.S 5325/2006 } \\
\text { (Not more } 0.1 \%)\end{array}$ \\
\hline
\end{tabular}

Table 2- The properties of properties of the fine and coarse aggregate used

\begin{tabular}{lcc}
\hline Test description & Sand & Basalt \\
\hline Volume weight & $1.74 \mathrm{t} / \mathrm{m}^{3}$ & $1.64 \mathrm{t} / \mathrm{m}^{3}$ \\
\hline Specific gravity & 2.65 & 2.81 \\
\hline Fineness modulus & 3.1 & ----- \\
\hline The ratio of fine materials & 0.8 & $0.5 \%$ \\
\hline Chloride content & $0.036 \%$ & $0.008 \%$ \\
\hline Sulfate content (SO3) & $0.18 \%$ & $0.059 \%$ \\
\hline Organic impurities & Nothing & Nothing \\
\hline Aggregate impact value & ------ & 10.75 \\
\hline Aggregate crushing value & ------ & $16.33 \%$ \\
\hline
\end{tabular}

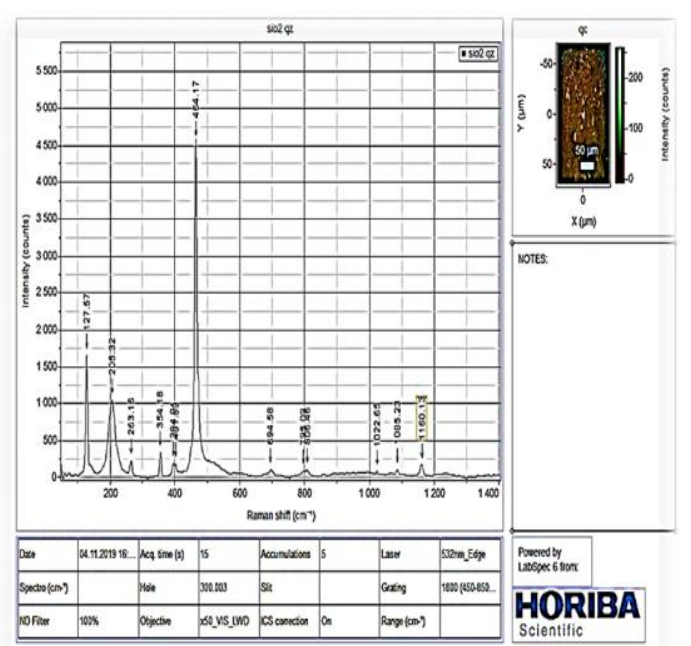

Figure 4- Raman shift shows the chemical composition of the sample consists mainly of $\mathrm{SiO}_{2}$

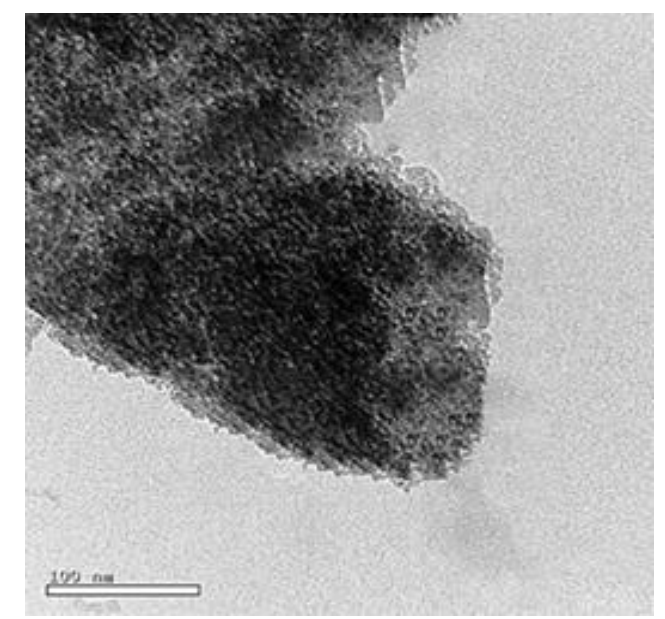

Figure 5- TEM image of Nano-quartz 


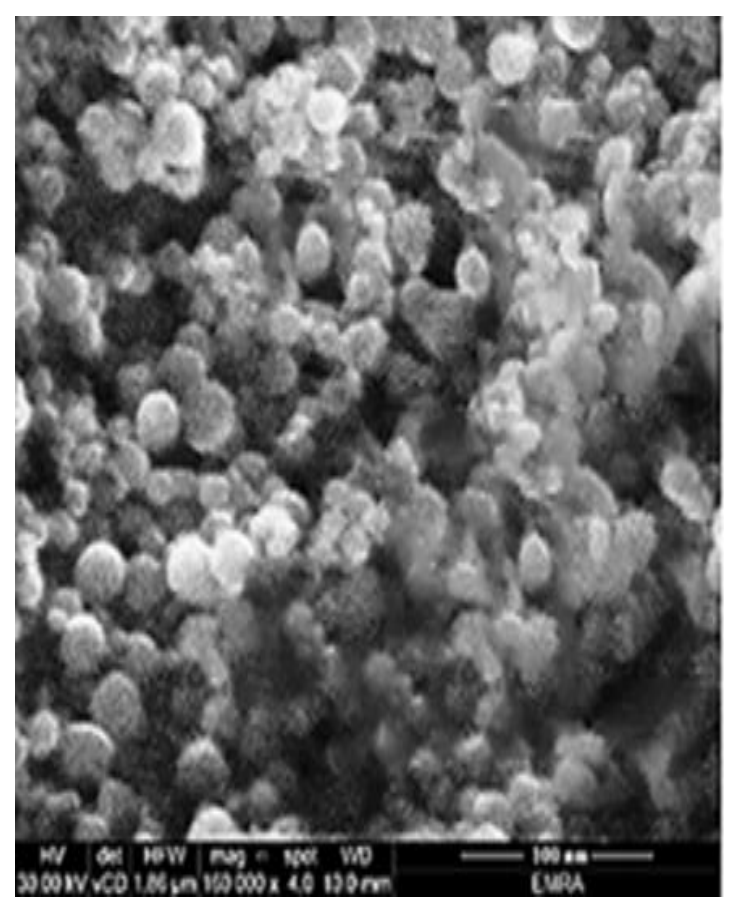

Figure 6- SEM image of Nano-quartz

All Nano-silica experiments were done in Egypt Nanotechnology Centre at Cairo University, El-Sheikh Zayed city. We use the following instruments in testing:

1. Nano Sight (NS500) Instrument (Malven, UK) was used to analyze the particle size and zeta potentials for the obtained Nano particles.

2. XRD for mineral identification carried out by Bruker company model D8 (including reflectometry, highresolution diffraction, in-plane grazing incidence diffraction (IP-GID), small angle X-ray scattering (SAXS), as well as residual stress and texture investigations).

3. Study surface area and pore volume using surface area and pore size analyzer model Nova Touch LX2 manufacture by Quanta Chrome Company made in the USA.

4. Raman spectrometer, which show $2 \mathrm{D}$ and $3 \mathrm{D}$ confocal images showed the shape of particles with different color (every color refer to one of chemical composition consist of materials) and its Raman shift determine the chemical composition with three different laser source $325 \mathrm{~nm}, 532 \mathrm{~nm}$ and $785 \mathrm{~nm}$.

5. AFM (Atomic Force microscope) Model 5600LS manufactured by Agilent Technology Company.

\section{Concrete Mixes}

In this study, high strength concrete was designed based on ACI 211-4R 93 guidelines by using excel sheet. The chosen concrete mix of HSC used is obtained based on research conducted by (Annadurai and Ravichandran, 2014) [27]. Totally ten mixes were used, the first was a control mix without any cement replacement. Three mixes were cast using silica fume $(5 \%, 10 \%$, or $15 \%$ as a replacement of cement weight). Three mixes were cast using Fly ash $(5 \%, 10 \%$, or $15 \%$ as a replacement of cement weight) and three mixes were designed with Nano-Silica quantities $5 \%, 10 \%$, or $15 \%$ as a replacement of cement weight), the Proportions of concrete Mixes used are shown in Table 3. The specimens demolded after 24 hours and kept curing until the day of the test. The experimental program is shown in Fig. 7; all tests were carried out according to Egyptian Standard Specifications (E.S.S.).

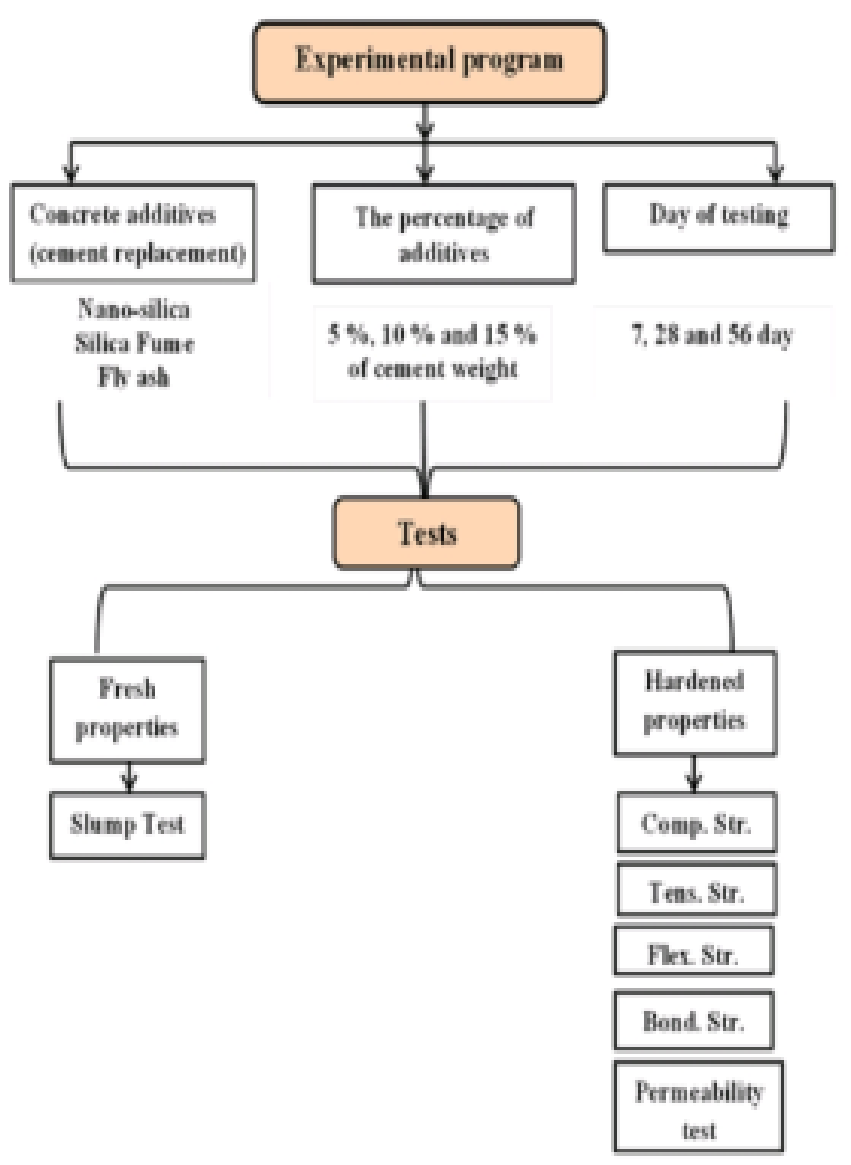

Figure 7- The flow chart of the experimental program 
Table 3- Proportion of concrete mixes used (stage 1 - conventional water curing)

\begin{tabular}{|c|c|c|c|c|c|c|c|c|c|c|c|c|c|}
\hline \multirow[b]{3}{*}{$\begin{array}{l}\stackrel{0}{8} \\
8 \\
\ddot{x} \\
\stackrel{x}{\Sigma}\end{array}$} & \multicolumn{8}{|c|}{ Components (kg) } & \multicolumn{5}{|c|}{ Tested samples } \\
\hline & \multirow[b]{2}{*}{$\mathrm{C}$} & \multirow[b]{2}{*}{$\mathrm{W}$} & \multirow[b]{2}{*}{ F.A } & \multirow[b]{2}{*}{ C.A } & \multirow[b]{2}{*}{ 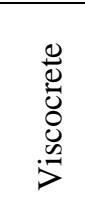 } & \multicolumn{3}{|c|}{ Cement replacement } & \multirow[b]{2}{*}{ 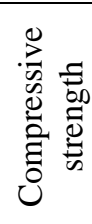 } & \multirow{2}{*}{ 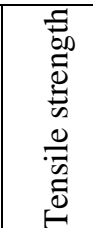 } & \multirow[b]{2}{*}{ 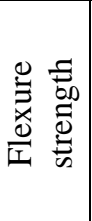 } & \multirow[b]{2}{*}{ 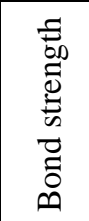 } & \multirow[b]{2}{*}{ 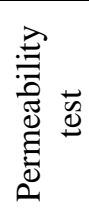 } \\
\hline & & & & & & 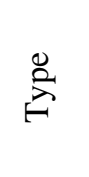 & 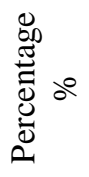 & $\begin{array}{l}\frac{\overrightarrow{0}}{500} \\
\frac{0}{0} \\
3\end{array}$ & & & & & \\
\hline B1 & 512 & 163 & 673 & 1174 & 2.56 & -- & -- & -- & \multirow{10}{*}{ 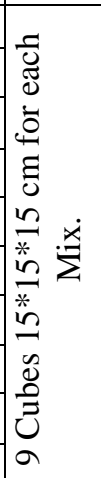 } & \multirow{10}{*}{ 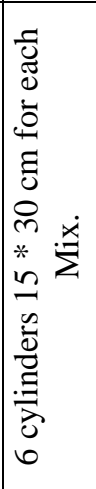 } & \multirow{10}{*}{ 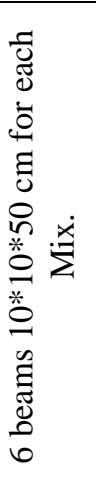 } & \multirow{10}{*}{ 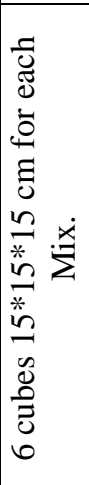 } & \multirow{10}{*}{ 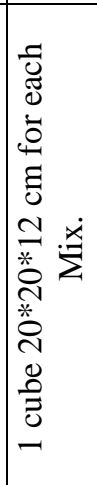 } \\
\hline NS1 & 486 & 163 & 673 & 1174 & 2.56 & \multirow{3}{*}{ 总: } & 5 & 25.6 & & & & & \\
\hline NS2 & 460 & 163 & 673 & 1174 & 2.56 & & 10 & 51.2 & & & & & \\
\hline NS3 & 435 & 163 & 673 & 1174 & 2.56 & & 15 & 76.8 & & & & & \\
\hline SF1 & 486 & 163 & 673 & 1174 & 2.56 & \multirow{3}{*}{ 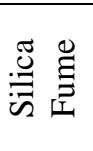 } & 5 & 25.6 & & & & & \\
\hline SF2 & 460 & 163 & 673 & 1174 & 2.56 & & 10 & 51.2 & & & & & \\
\hline SF3 & 435 & 163 & 673 & 1174 & 2.56 & & 15 & 76.8 & & & & & \\
\hline$\overline{\text { FA1 }}$ & 486 & 163 & 673 & 1174 & 2.56 & \multirow{3}{*}{ 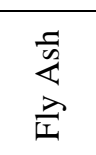 } & 5 & 25.6 & & & & & \\
\hline FA2 & 460 & 163 & 673 & 1174 & 2.56 & & 10 & 51.2 & & & & & \\
\hline$\overline{\mathrm{FA3}}$ & 435 & 163 & 673 & 1174 & $\overline{2.56}$ & & 15 & 76.8 & & & & & \\
\hline
\end{tabular}

\section{Test specimens}

The specimens used in this study were categorized into five standard groups of samples. Concrete cubes $15 \times 15$ $\mathrm{x} 15 \mathrm{~cm}$ to determine the compressive strength of concrete mixes. Cylinders with $15 \mathrm{~cm}$ diameter and 30 $\mathrm{cm}$ height were used to determine the tensile strength of concrete mixes. Prisms with a square section of $10 \mathrm{~cm}$ side length and $50 \mathrm{~cm}$ total length were used to determine the flexural strength of concrete mixes. Concrete cubes $15 \times 15 \times 15 \mathrm{~cm}$ were used to determine the bond strength of concrete mixes. Permeability tests were conducted by using cubes with dimensions of $20 \mathrm{x}$ $20 \times 12 \mathrm{~cm}$ to study the penetration depth of water under pressure in concrete.

\section{RESULTS AND DISCUSSION}

\section{Fresh Properties of Concrete Mix}

The Fresh concrete properties represented in the slump values were conducted for all concrete mixes to show the variation of using different supplementary cementious materials (Nano-silica, Silica-fume, and Fly-ash) with different ratios. The results are shown in Table 4 . The slump value decreases as increasing the dosages of Nano-silica, Silica-fume and Fly-Ash. Also, it shows that the flowability of concrete mixes contains Nano-silica is lower than concrete mixes contain Silica-fume. Concrete mixes with fly-ash show high slump values. That may be led to segregation in concrete. So, reducing the super plasticizer dosage with using fly-ash is recommended.

As the fineness of supplementary cementious materials increases, the surface area becomes larger which requires more water for hydration or for workability. Using different supplementary cementious materials requires a different dosage of chemical admixtures.
Table 4- Slump values of different mixes

\begin{tabular}{lccc}
\hline \multicolumn{2}{c}{ Mixes } & Slump \\
$\begin{array}{l}\text { Supplementary } \\
\text { cementious materials }\end{array}$ & Ratio & Code & $\begin{array}{c}\text { Value } \\
(\mathrm{mm})\end{array}$ \\
\hline Control mix & 0 & C.M. & 200 \\
\hline \multirow{2}{*}{ Nano-Silica } & $5 \%$ & NS1 & 125 \\
& $10 \%$ & NS2 & 90 \\
& $15 \%$ & NS3 & 70 \\
\hline \multirow{2}{*}{ Silica-Fume } & $5 \%$ & SF1 & 200 \\
& $10 \%$ & SF2 & 165 \\
& $15 \%$ & SF3 & 135 \\
Fly-Ash & $5 \%$ & FA1 & 250 \\
& $10 \%$ & FA2 & 230 \\
& $15 \%$ & FA3 & 210 \\
\hline
\end{tabular}

\section{Mechanical Properties}

The main studied mechanical properties are compressive, splitting tensile, flexural, bond strengths and permeability test. The results are shown in Table 5. and Figs. 8. to 12. Results obtained from the compressive strength test are plotted graphically as reported in Fig. 8 . The compressive strength of the control mixture compared to the other concrete mixtures to show the impact of using different supplementary cementious materials with different ratios. The concrete mixture with $5 \%$ fly ash content show a little increase in compressive strength by about $0.2 \%$ after 28 days and $3.3 \%$ after 56 days than the control mixture, while the concrete mixture with $10 \%$ fly ash content decreased by about $16 \%$ than the control mixture, and the concrete mixture with $15 \%$ fly ash content decreased by about $19 \%$ than the control mixture. The decrease of compressive strength may cause due to constant $\mathrm{w} / \mathrm{cm}$, that fly ash require reducing water content by approximately $3 \%$ for each $10 \%$ fly ash compared to similar mix without fly ash [28]. The delay of the hydration process for the specimens with fly ash. 
At early ages, the compressive strength of fly ash concrete is less than the control mixture. Concrete with high percentages of fly ash can be used in situations where strength is not important economy is required. The decrease of compressive strength may cause due to constant $\mathrm{w} / \mathrm{cm}$, that fly ash require reducing water content by approximately $3 \%$ for each $10 \%$ fly ash compared to similar mix without fly ash That is in agreeing with other researches [29, 30, 31].

The concrete mixture with $5 \%$ silica fume content show an increment in compressive strength by about $4.0 \%$ after 28 days, with increasing silica fume ratios up to $10 \%$ the compressive strength increased by about $9.7 \%$ after 28 days. While the concrete mixture with $15 \%$ silica fume content increased by about $6.4 \%$ than the control mixture, but it is less than the concrete mixtures with $10 \%$ silica fume. Silica fume increases the concrete properties by two ways: first, its small particles act as a filler for the spaces between cement and aggregate particles. Second, SF reacts with $\mathrm{CH}$ to produce a greater solid volume of $\mathrm{C}-\mathrm{S}-\mathrm{H}$ gel, tends to an additional reduction in capillary porosity during hydration. This result is matched with (Saini and Nayak, 2019) [32]. The concrete mixture with $5 \%$ Nano-silica content show an increment in compressive strength by about $9.7 \%$ after 28 days than the control mixture. While concrete mixture with $10 \%$ Nano-silica content show an increment in compressive strength by about $7.3 \%$ after 28 days than the control mixture, although it is less than that mix with $5 \%$ Nano-silica. While concrete mixture with $15 \%$ Nanosilica content show an increment in compressive strength by about $5.1 \%$ after 28 days compared to the control mixture. Nano-silica increases the compressive strength and enhance the mechanical properties of concrete, this can be attributed to the reaction of silica with calcium hydroxide (pozzolanic reaction) resulted from cement hydration besides the formation of $\mathrm{C}-\mathrm{S}-\mathrm{H}$ gel. Also, the high specific surface of NS enables it to do very well. Where the compressive strength decreases with the increasing Nano-silica ratio, but it is still greater than the control mix compressive strength. That was explained as follows: as the quantity of $\mathrm{SiO}_{2}$ Nano-particles added to the mix is greater than that needed to syndicate with the liberated lime through the hydration process, the extra silica, which does not contribute to concrete strength, replaces portions of the CMs materials and thus decreased the strength. When the NS percentage is large, the weak zone in concrete increases then compressive strength decreases. This decrease is owing to the agglomeration and defects generated in the dispersion of NS particles this result is matched with (Sharaky et. al., 2019) [33].

Results obtained from the tensile strength test are plotted graphically as reported in Fig. 9. The tensile strength of the control mixture compared to the other concrete mixtures to show the impact of using different supplementary cementious materials with different ratios. The concrete mixtures containing fly ash have higher tensile strength than control mixture, the tensile strength decreases with increasing fly ash. The concrete mixtures with $5 \%, 10 \%$, and $15 \%$ of fly ash content show an increment in tensile strength by about $13 \%$, $10 \%$ and $5 \%$, respectively after 28 days compared to the control mix. The concrete mixtures with $5 \%, 10 \%$ and $15 \%$ silica fume content show enhancement in tensile strength by about $18 \%, 27 \%$ and $17 \%$, respectively compared to the control mix after 28 days. When using Nano-silica in concrete mixes as $5 \%, 10 \%$ and $15 \%$ of cement content, an enhancement in tensile strength by about $62 \%, 53 \%$ and $32 \%$, respectively were obtained compared to the control mixture after 28 days. Better split tensile strengths were obtained in the concretes blended with nanoparticles in comparison to the control concrete. . The strength increases may be attributed to the pozzolanic reaction and filler effect of nanosilica and the reason for the reduced strength improvement at later ages may be due to lack of proper dispersion of the nanosilica particles and the lack of formation of calcium hydroxide at later ages for the pozzolanic reaction of unreacted silica fume. This result is matched with (Ganesh, R. Murthy, S. Kumar, M. S. Reheman and Iyer, November 2015) [34].

Table 5- The test results of hardened properties of concrete mixes

\begin{tabular}{|c|c|c|c|c|c|c|c|c|c|c|c|c|c|}
\hline \multirow[t]{2}{*}{$\begin{array}{l}\text { Mix } \\
\text { Code }\end{array}$} & \multicolumn{3}{|c|}{$\begin{array}{c}\text { Compressive Strength } \\
\qquad(M P a)\end{array}$} & \multicolumn{3}{|c|}{$\begin{array}{l}\text { Tensile Strength } \\
\qquad(M P a)\end{array}$} & \multicolumn{3}{|c|}{$\begin{array}{l}\text { Flexural Strength } \\
\qquad(M P a)\end{array}$} & \multicolumn{3}{|c|}{$\begin{array}{l}\text { Bond Strength } \\
\qquad(\mathrm{MPa})\end{array}$} & \multirow{2}{*}{$\begin{array}{c}\text { Permeability } \\
\text { test }(\mathrm{mm})\end{array}$} \\
\hline & $\begin{array}{c}7 \\
\text { days }\end{array}$ & $\begin{array}{c}28 \\
\text { days }\end{array}$ & $\begin{array}{c}56 \\
\text { days }\end{array}$ & $\begin{array}{c}7 \\
\text { days }\end{array}$ & 28 days & $\begin{array}{c}56 \\
\text { days }\end{array}$ & $\begin{array}{c}7 \\
\text { days }\end{array}$ & $\begin{array}{c}28 \\
\text { days }\end{array}$ & $\begin{array}{c}56 \\
\text { days }\end{array}$ & $\begin{array}{c}7 \\
\text { days }\end{array}$ & $\begin{array}{c}28 \\
\text { days }\end{array}$ & $\begin{array}{c}56 \\
\text { days }\end{array}$ & \\
\hline C.M & 50.3 & 60.78 & 61.8 & 2.67 & 3.31 & 4 & 6.28 & 7.31 & 8.91 & 21.22 & 25.46 & 27.58 & 9 \\
\hline FA1 & 50.7 & 60.9 & 63.87 & 3.19 & 3.76 & 4.1 & 6.37 & 10.3 & 10.53 & 22.28 & 26.34 & 29.7 & 36 \\
\hline FA2 & 46.6 & 50.76 & 56.3 & 3.1 & 3.65 & 3.89 & 6.51 & 10.1 & 10.18 & 18.1 & 20.16 & 25.46 & 26 \\
\hline FA3 & 43.1 & 48.77 & 54.87 & 3 & 3.5 & 3.89 & 6.52 & 9.05 & 9.36 & 17.5 & 20.00 & 23.34 & 15 \\
\hline SF1 & 52.5 & 63.4 & 66.6 & 3.3 & 3.92 & 4.53 & 8.196 & 9.11 & 9.88 & 28.6 & 38.2 & 38.2 & 0 \\
\hline SF2 & 55.9 & 66.5 & 67.95 & 3.83 & 4.22 & 4.66 & 9.66 & 9.81 & 10.44 & 28.6 & 40.32 & 42.44 & 4 \\
\hline SF3 & 55.1 & 64.7 & 66.16 & 3.89 & 3.89 & 4.11 & 9.62 & 9.74 & 10.23 & 27.58 & 39.38 & 41.44 & 8 \\
\hline NS1 & 63.4 & 66.74 & 67.6 & 5.01 & 5.38 & 5.38 & 10.8 & 11.5 & 12.46 & 38.1 & 40.32 & 41.8 & 0 \\
\hline NS2 & 60.8 & 65.23 & 65.91 & 4.88 & 5.09 & 5.28 & 8.11 & 8.77 & 8.78 & 33 & 35.01 & 36.8 & 0 \\
\hline NS3 & 59.2 & 63.87 & 64.1 & 4.01 & 4.38 & 4.48 & 8 & 8.68 & 8.68 & 30.91 & 33.95 & 34.8 & 8 \\
\hline
\end{tabular}


Results obtained from the flexural strength test are plotted graphically as reported in Fig. 10. The flexural strength of the control mixture was compared to the other concrete mixtures to show the impact of using different supplementary cementious materials with different ratios. The concrete mixtures containing fly ash have higher flexural strength than control mixture, but the flexural strength decreases with increasing fly ash content. The concrete mixture with $5 \%, 10 \%$ and $15 \%$ fly ash content show an increment of flexural strength by about $41 \%, 38 \%$ and $23 \%$, respectively after 28 days than the control mixture. The concrete mixtures with 5\%, $10 \%$ and $15 \%$ of silica fume content show enhancement of flexural strength by about $24 \%, 34 \%$ and $33 \%$, respectively than the control mixture after 28 days. While concrete mixtures with $5 \%, 10 \%$ and $15 \%$ of Nano-silica content show enhancement of flexural strength by about $57 \%, 19 \%$ and $18 \%$, respectively than the control mixture after 28 days.

Results obtained from the bond strength test are plotted graphically as reported in Fig.11. The bond strength of the control mixture compared to the other concrete mixtures to show the impact of using different supplementary cementious materials with different ratios. The concrete mixtures containing $5 \%$ of fly ash have higher bond strength than control mixture. The bond strength decreases with increasing fly ash. The concrete mixture with $5 \%$ fly ash content show an increment in flexure strength by about $35 \%$ after 28 days compared to the control mixture. As used $10 \%$ and $15 \%$ of fly ash content there is a decrease in bond strength by about $20 \%$ and $21 \%$, respectively after 28 days compared to the control mixture. The concrete mixtures with $5 \%$, $10 \%$ and $15 \%$ silica fume content show enhancement in bond strength by about $50 \%, 58 \%$ and $54 \%$, respectively than the control mixture after 28 days. While concrete mixtures with $5 \%, 10 \%$ and $15 \%$ Nano-silica content show enhancement in bond strength by about $58 \%, 37 \%$ and $33 \%$, respectively than the control mixture after 28 days.

Results obtained from the permeability test are plotted graphically as reported in Fig. 12. The permeability test expressed by the penetration depth of water in concrete samples. The penetration depth decrease with increasing fly ash content and all concrete mixtures containing fly ash have a higher penetration depth than the control mixture. The penetration depth increases with the increasing silica fume content and all concrete mixtures containing silica fume have a lower penetration depth than the control mixture. The best samples showed in permeability test are represented by $5 \%$ and $10 \%$ Nanosilica concrete mixtures and $5 \%$ silica fume concrete mixtures that its value is zero (no penetration of water in the concrete). The penetration depth of the concrete mixtures containing $10 \%$ silica fume as a replacement of cement decreased by about $55 \%$ than the control mixture after 28 days.

Generally, high strength concrete "HSC" requires a higher quality of the materials used so it is preferred to use fine aggregates with a high value of fineness modulus and clear of fine materials and the type of coarse aggregate is very important in high strength concrete and has a great influence on the concrete strength. High strength concrete requires a low w/c ratio, so the use of superplasticizer enhances the main fresh and hardened concrete properties and decrease water content in concrete mixture. The strength of concrete varies accordingly the cement grade and its chemical composition.

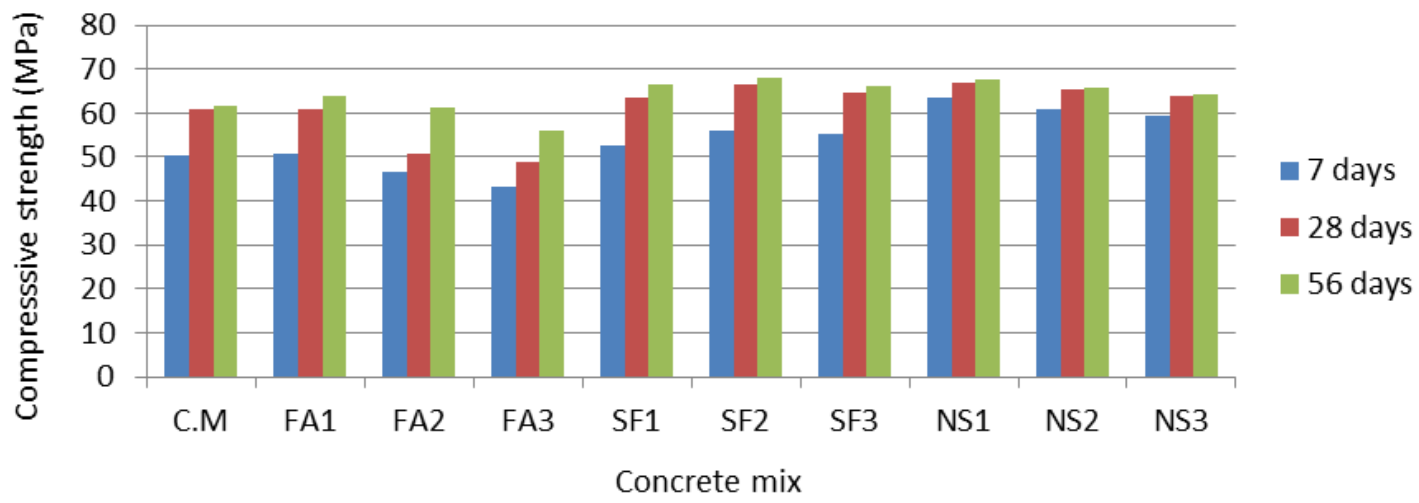

Figure 8- Compressive strength of HSC using different ratios (5\%, 10\%, and 15\%) of fly ash, silica fume and Nano-silica compared to control mix at 7, 28 and 56 days 


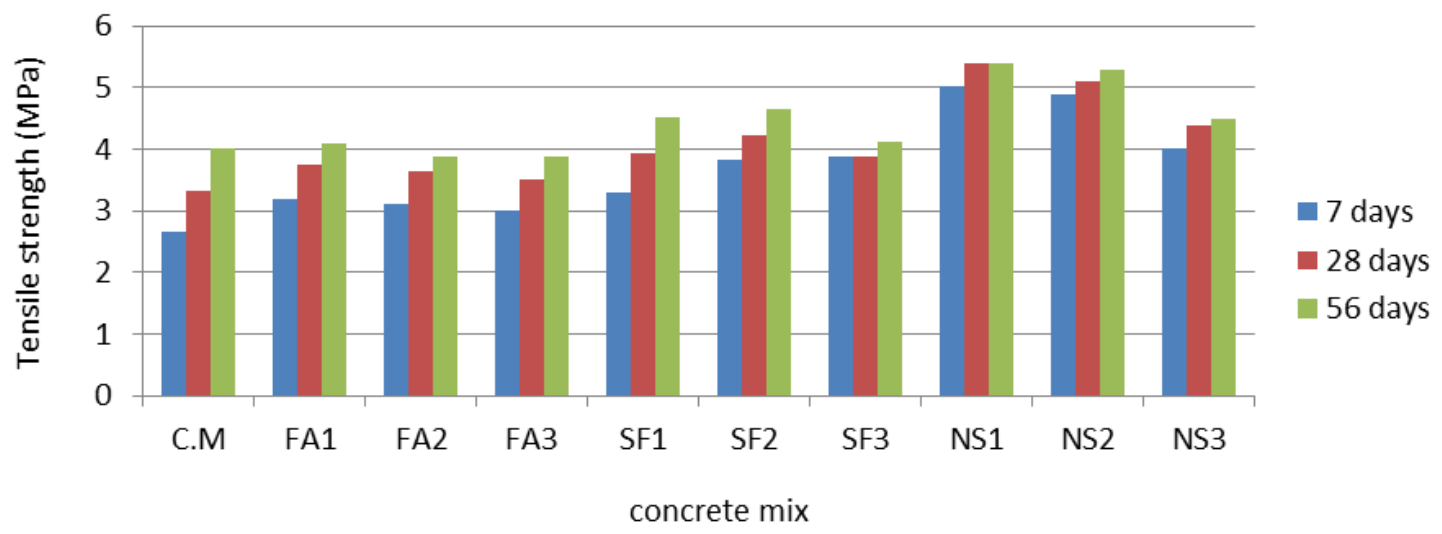

Figure 9- Tensile strength of HSC using different ratios (5\%,10\%, and 15\%) of fly ash, silica fume and Nano-silica compared to control mix at 7, 28 and 56 days

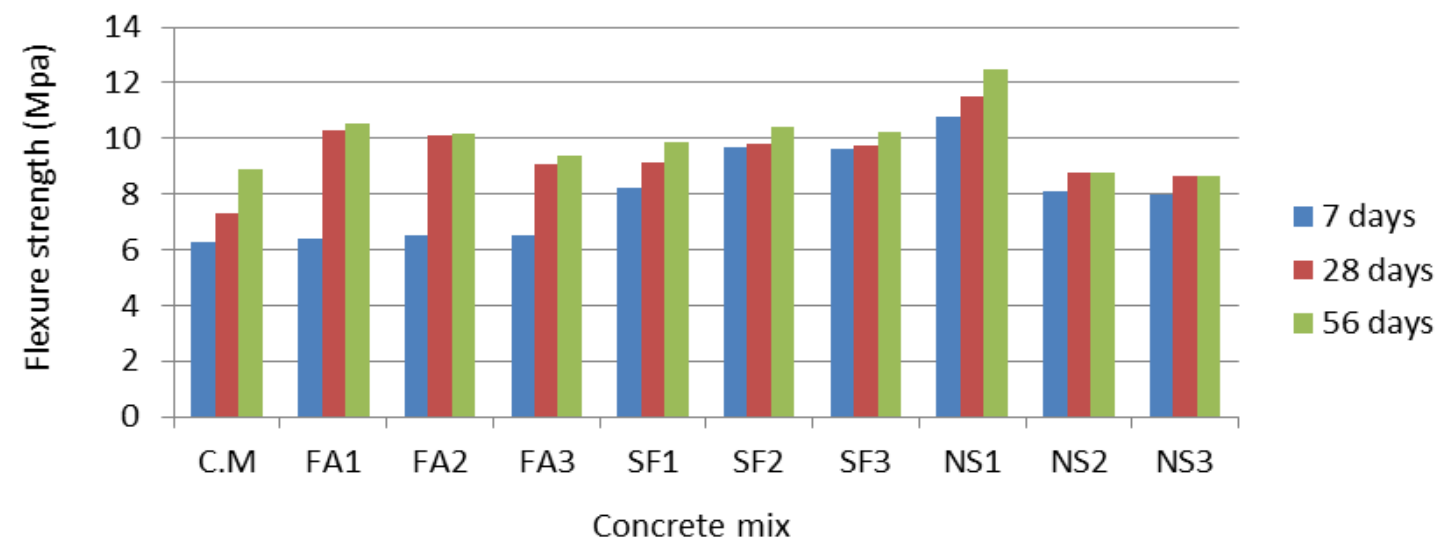

Figure 10- Flexure strength of HSC using different ratios (5\%, 10\%, and $15 \%)$ of fly ash, silica fume and Nano-silica compared to control mix at 7,28 and 56 days

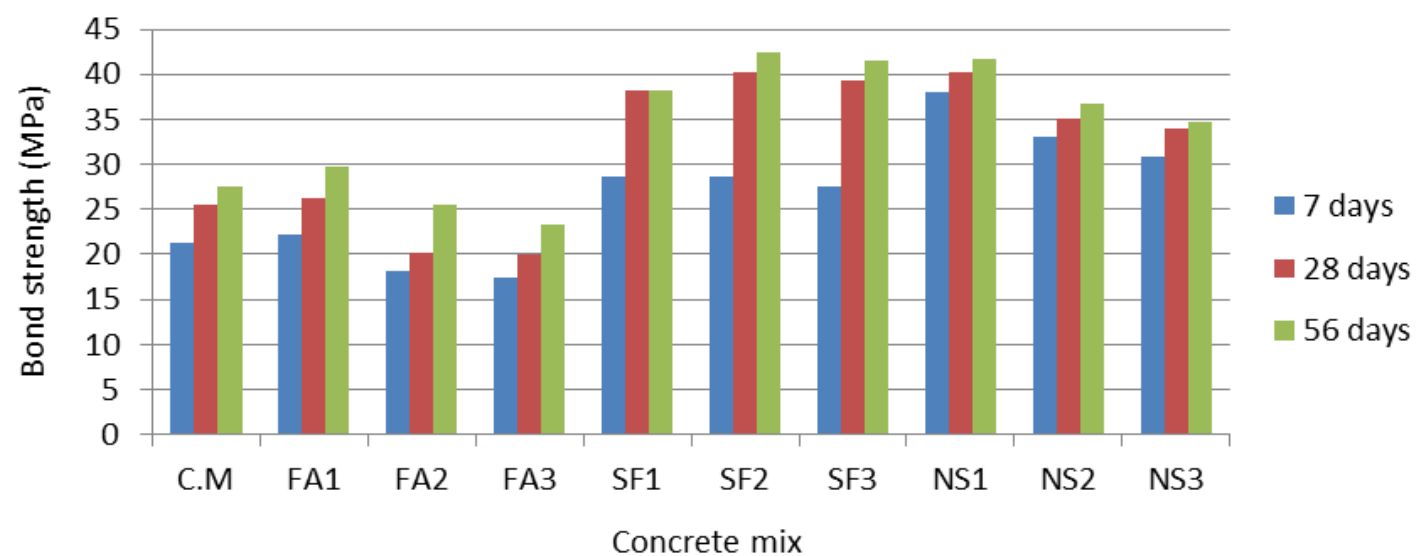

Figure 11- Bond strength of HSC using different ratios (5\%, 10\%, and 15\%) of fly ash, silica fume and Nano-silica compared to control mix at 7,28 and 56 days 


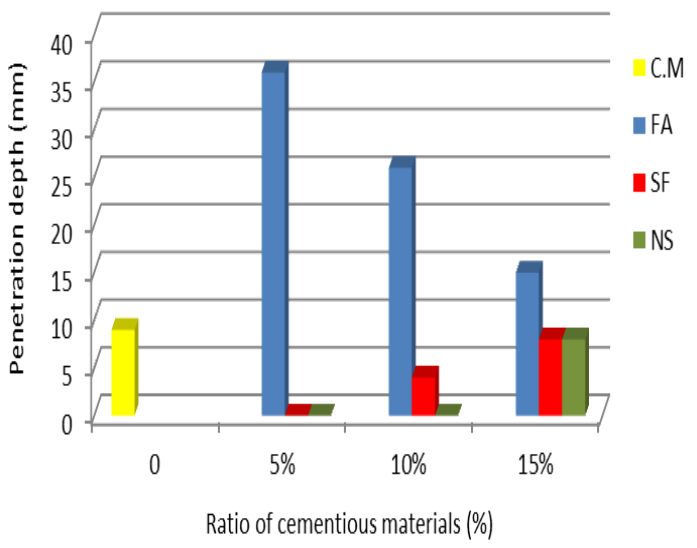

Figure 12- Permeability of HSC using different ratios $(5 \%, 10 \%$, and $15 \%)$ of fly ash, silica fume and Nano-silica compared to control mix after 28 days

\section{CONCLUSIONS}

The main conclusions based on the results of this study can be summarized as follows:

1. Slump values decrease with the increasing of supplementary cementious materials. Slump values decrease in concrete mixes with Nano-silica than that with silica fume and fly ash due to its large surface area.

2. Using silica fume and Nano-silica improves the main properties of high strength concrete.

3. The compressive strength of fly ash concrete mixtures decreases with the increasing of fly ash content in concrete mixtures according to this study. The compressive strength of concrete samples with $5 \%$ of fly ash slightly higher than the control samples, while the compressive strength of $10 \%$ and $15 \%$ fly ash concrete samples was less than that for control samples.

4. The compressive strength of concrete mixtures containing silica fume higher than control mixtures.

5. The compressive strength of concrete mixes with silica fume increases with the increasing of silica fume content in concrete mixtures up to about $10 \%$ content It show a decrease in the compressive strength as using $15 \%$ silica fume content. The best results achieved by using silica fume as $10 \%$ of cement content.

6. All concrete mixtures containing Nano-silica achieved a higher compressive strength than the control mixtures. Using dosages more than $5 \%$ of Nano-silica leads to reverse results that the test results showed a decrease in the compressive strength of concrete mixtures as increasing the Nano-silica content.

7. Tensile strength improved as using fine materials, especially as using silica fume and Nano-silica. As used silica fume as $10 \%$ of cement content, the best tensile strength obtained. As using Nano-silica, the best tensile strength value obtained by using a ratio of $5 \%$. The tensile strength increases as using pozzolanic admixtures up to optimum value, then decrease as increasing their content.

8. All concrete mixtures containing fly ash, silica fume and Nano-silica have a higher flexure strength than the control mixture. The best flexure strength results of tested mixes obtained as using 5\% Nano-silica or as using $10 \%$ silica fume concrete mixture or as using $10 \%$ fly ash as additive in concrete mixtures. The flexure strength increases by adding fly ash, silica fume or Nano-silica in concrete mixes up to optimum value, then it decreases as increasing their dosage.

9. The bond strength increases up to optimum value, then it decreases as increasing the content of fly ash, silica fume or Nano-silica in concrete mixes as pozzolanic additives. In silica fume concrete mixes the best bond strength values achieved by using $10 \%$ of silica fume or as using 5\% Nano-silica concrete mixtures.

10. When considering the permeability of obtained concrete, the fly ash concrete mixtures show a high rate of water penetration depth, the Nano-silica concrete mixture is impermeable concrete and show no penetration depth, in silica fume concrete mixtures the penetration depth increases with increasing silica fume content. The best results of the permeability test represented by $5 \%$ and $10 \%$ Nano-silica concrete mixtures and $5 \%$ silica fume concrete mixture that show no penetration depth which considered impermeable concrete.

11. Using pozzolanic admixtures is effective to improve the strength and permeability of high strength concrete. The strength increases by adding fly ash, silica fume or Nano-silica in concrete mixes up to optimum dosage, then it decreases as increasing their content. 


\section{REFERENCES}

[1] T.R. Naik, F.ASCE, 2008, "Sustainability of concrete construction" Practice Periodical on Structural Design and Construction, vol. 13, Issue 2, pp. 98-103.

[2] K. L. Scrivener, V. M. John, E. M. Gartner (2016) Eco-efficient cements: potential, economically viable solutions for a low-CO2, cement-based materials industry. Cement Concrete Res 114:2-26. United Nations Environment Program. www.unep.org

[3] B. K. K. Bai and M. K. Rao, "Strength and Durability Properties of High Performance Concrete Incorporating Silica Fume and Fly Ash," International Journal of Engineering Sciences and Emerging Technologies "IJESET", vol. 8, no. 1, pp. 23-29, 2015.

[4] N. N. Meleka, A. A. Bashandy and M. A. Arab, "Ultra-High Strength Concrete Using Economical Materials," International Journal of Current Engineering and Technology IJCET, vol. 3, no. 2, pp. 393-402, 2013.

[5] O. M. A. Daoud and H. S. Sagady, " Production and Properties of High Strength Concrete for Heightening Concrete Dam in Sudan" Int. J. of GEOMATE, June, 2013, Vol. 4, No. 2 (Sl. No. 8), pp. 539-545. Geotec., Const. Mat. \& Env., Japan.

[6] M. Kumar and Z. Ma, "Mechanical Properties of High-Strength Concrete," 2012 Materials Journal.

[7] M. M. Kamal, M. A. Safan, A. A. Bashandy and A. M. Khalil, "Experimental Investigation on the Behavior of Normal Strength and High Strength Self-curing Self-compacting Concrete," Journal of Building Engineering, vol. 16, no. 1, p. 79-93, 2018

[8] M. M. Emad, N. M. Soliman and A. A. Bashandy, "Recycled Aggregate High-Strength Concrete," International Journal of Civil Engineering and Technology "IJCIET" (ISSN 0976-6316), vol. 10, no. 9, pp. 128-146, 2019.

[9] A. A. Bashandy, N. M. Soliman and M. H. AbdElrahman, "Recycled Aggregate Self-curing Highstrength Concrete," Civil Engineering Journal (ISSN 2476-3055), vol. 3, no. 6, pp. 427-441, 2017.

[10] M. Mittal, S. Basu and A. Sofi, "Effect of Sika Viscocrete on Properties of Concrete," International Journal of Civil Engineering (IJCE), vol. 2, no. 4, pp. 61-66, 2013.

[11] J. J. Gaitero, I. Campillo, P. Mondal and S. P. Shah, 2010, "Small Changes Can Make a Great Difference" In Transportation Research Record, Journal of the Transportation. Volume: 2141, issue: 1 , page(s): $1-5$
[12] J.Song, and S. Liu. "Properties of Reactive Powder Concrete and its Application in Highway Bridge." Advances in Materials Science and Engineering (2016).

[13] B. S. Mohammed, V. C. Khed and M. Fadhil, 2017, "A Review on Nano-silica Based Concrete," J Nanomed Nanoscience: JNAN-128, Volume 02; Issue 05. DOI: 10.29011/.

[14] S. Du, O. Alshareedah and X. Shi, "Nanotechnology in Cement-Based Materials: A Review of Durability, Modelin 5g, and Advanced Characterization," Nanomaterials, vol. 9, no. 9, 2019.

[15] R. Siddique and M. I. Khan, "Supplementary Cementing Materials, Silica Fume," XVI Publishers, 288 P, ISBN: 978- 3-642-17865-8, p. $288,2011$.

[16] A. Bashir, M. Gul, J. A Naqash, A. Masood, " Study of Permeability and Compressive Strength of Silica Fume Concrete" International Journal of Engineering and Advanced Technology (IJEAT) ISSN: 2249 - 8958, Volume-3, Issue-4, April 2014.

[17] M. N. Haque and O. Kayali, "Properties of HighStrength Concrete Using a Fine Fly Ash," Cement Concrete Research, vol. 28, no. 10, pp. 1445-1452, 1998.

[18] M. A. Rasol, "Effect of Silica Fume on Concrete Properties and Advantages for Kurdistan Region, Iraq," International Journal of Scientific and Engineering Research, vol. 6, no. 1, pp. 170-173, 2015.

[19] T. Sankaralingam, A. Chandanroy and S. N. Pandey, "Fly Ash For Cement Concrete," Ash Utilization Division-NTPC Limited, A-11, NFL Premises, Sector-24, Noida-201301, 2007.

[20] M.Tokyay, "Cement and Concrete Mineral Admixtures". CRC Press, 2016.

[21] K. N. Ismail, K. Hussin and M. S. Idris, "Physical, Chemical and Mineralogical Properties of Fly Ash," Journal of Nuclear and Related Technology, vol. 4, no. Special Edd., pp. 47-51, 2007.

[22] N. Gamage, K. Liyanage, S. Fragomeni and S. Setunge, "Overview of Different Types of Fly Ash and their use as a Building and Construction Material," in International Conference of Structural Engineering, Construction and Management, 2011.

[23] G. Li, "Properties of High-volume Fly Ash Concrete Incorporating Nano-SiO $\mathrm{S}_{2}$, Cement and Concrete Research, vol. 33, no. 6, pp. 799-806, 2003.

[24] P. Nath and P. Sarker, "Effect of Fly Ash on the Durability Properties of High Strength Concrete," Procedia Engineering, vol. 14, p. 1149-1156, 2011. 
[25] A. M. Said, M. S. Zeidan, M. T. Bassuoni and Y. Tian, "Properties of Concrete Incorporating Nanosilica," Construction and Building Materials, vol. 36, pp. 838-844, 2012.

[26] O. S. B. Al-Amoudi, M. .. Maslehuddin and T. O. Abiola, "Effect of Type and Dosage of Silica Fume on Plastic Shrinkage in Concrete Exposed to Hot Weather," Construction and Building Materials, vol. 18, no. 10, pp. 737-743, 2004.

[27] A. Annadurai and A. Ravichandran, "Development of Mix Design for High Strength Concrete with Admixtures," IOSR Journal of Mechanical and Civil Engineering (IOSR-JMCE), vol. 10, no. 5, pp. 22-27, 2014.

[28] M. Thomas, 2007, "Optimizing the Use of Fly Ash in Concrete" Portland Cement Association, Publication IS548, 2007, pp. 24.

[29] A. V. Rao and K. S. Rao, "Effect of Fly Ash on Mechanical Properties of M30 and M60 Grade Concrete," International Journal of Civil Engineering and Technology (IJCIET), vol. 8, no. 3, p. 193-200, 2017.
[30] A. V. Rao and K. S. Rao, "Effect of Fly Ash on Strength of Concrete," Circular Economy and Fly Ash Management, vol. 8, no. 3S, pp. 125-134, 2019.

[31] M. Thomas, 2007, "Optimizing the Use of Fly Ash in Concrete" Portland Cement Association, Publication IS548, 2007, pp. 24.

[32] L. K. Saini and J. R. Nayak, "To Study Effects on the Mechanical Properties of Concrete after Partially Replacing Cement by Silica Fume," International Research Journal of Engineering and Technology (IRJET), vol. 6, no. 9, pp. 752-755, 2019.

[33] I. A. Sharaky, F. A. Megahed, M. H. Seleem and A. M. Badawy, "The Influence of Silica Fume, Nano Silica and Mixing Method on the Strength and Durability of Concrete," SN Applied Sciences, vol. 575, 2019.

[34] Ganesh, R. Murthy, S. Kumar, M. S. Reheman and Iyer, "Effect of nanosilica on durability and mechanical properties of high-strength concrete," Magazine of Concrete Research, November 2015, Volume:68, pp. 1-8. 